\title{
Development of Biodegradable Board using Water Hyacinth (Eichornia crassipes)
}

\author{
Winda Rahmawati, Agus Haryanto, Siti Suharyatun
}

Department of Agricultural and Biological Engineering, University of Lampung, Bandar Lampung, Indonesia

\begin{abstract}
The aim of this study was to utilized aquatic weed to become a bio-board with proper mechanical properties. Water hyacinth (Eichornia crassipes) is aquatic weed with rapid growing rate that usually clog the irrigation facility and cover the river surface cause negative impact to environment usually water environment. In this research water hyacinth was used to produced bio-boards through cutting, soaking, refining, molding, and drying process with applied of five different loading pressures (2MPa, 3.5MPa, 5MPa, 6.5MPa, $8 \mathrm{MPa}$ ) in applied of 110 degree Celsius. In the producing process of bio-board hydrogen bond among the cellulose fiber were used instead of used chemical substance and additional additive. Bio-boards were successfully produced under experimental condition. Mechanical properties of each bio-board were investigated. Result of water hyacinth bio-board density was $1.1691 \mathrm{~g} / \mathrm{cm}$ average bending rupture stress 46.21 $\mathrm{MPa}$ and tensile rupture stress in average value was 6.64MPa. Bio-board with certain different strength range could be considered to be applied as packaging, seedling pot, mulching or insulating material in advance application
\end{abstract}

Keywords - agriculture waste, bio-board, utilization, water hyacinth.

\section{INTRODUCTION}

About 6 million $\mathrm{m}^{3}$ wood is used for the timber industry, including the production of pulp each year in Indonesia (Ministry of Environment Republic Indonesia, 2012). Wood has many uses in daily life; it is the main cellulose source for housing, furniture, packaging, paper, and other products. In 2007 about 66.2 percent of industrial forest plantation was planted for pulpwood plantation type. During the period 1993-2006, the pulpwood plantation sharply increased from 29,000 ha in 1989 to 200,000 in 2006 with average of 104,000 ha per year (FAO,2009). Those data indicated that wood demand for pulp industry continues to grow in Indonesia, however local forest production have been unable to meet the increasing demand.

Wood based product demand has been increasing nowadays. Wood based product such as, packaging, wall layer, seedling pots and others product which are daily consume product. The increasing demand for wood based products will impact on increasing the amount of logging, both industrial plantations and forests in general. Intensive use of wood can cause environmental problems such as deforestation, floods, and also global warming.

To overcome these problems, researchers have focused on finding others renewable resources to replace the use of wood for some uses. There is some non-wood which potential resources to be use as pulping material and other wood based product. Intensive use of wood as main cellulose source can be decreased by substituted by other cellulose source material such as biomass.

In this research, water hyacinth (Eichornia crassipes) the free-floating aquatic macrophyte growing generally to 0.5 meters that can grow and spread rapidly during rainy season. Water hyacinth is consider as weed (pest) and an unwanted plant. Due to its fast growth and rapid spread, water hyacinth has caused some problem such as the reduction of fish, wide coverage the river surfaces and canals, clogging irrigation facilities and water pollution. Attempts to control or remove the water hyacinth incur high cost and labor and the effect just temporary due to rapid growth.

Based on research conducted by Pasaribu and Swahlita (2007), known that moisture content of fresh water hyacinth is $94.25 \%$ with yield of pulp in dry condition of $3.6 \%$. About $1 \mathrm{~m}^{2}$ of area has $28 \mathrm{~kg}$ of fresh water hyacinth, mostly (84\%) from those fresh water hyacinth is stem. Water hyacinth is low in lignin content $(10 \%)$ and contains high amounts of cellulose (60\%) and hemicellulose $(33 \%)$. Water hyacinth currently used as craft and compost (Gunnarson and Petterson ,2007). Recently, bio- board that already developed made from bagasse (sugar cane waste), rice straw, wheat straw and corn straw successfully.

The aims of this research were to utilize water hyacinth to produce bio-board, analyze characteristic of bio-boards from three different biomasses. Physical characteristic such as density, moisture content, bending stress and tensile stress of bio-board were investigated. Producing bio-board with 5 different loading pressures will result in different mechanical properties of bio-boards.

Water hyacinth bio-board produce through a cutting, milling, soaking, refining, soaking pulp and molding 
process with applied of five different loading pressures (2 $\mathrm{MPa}, 3.5 \mathrm{MPa}, 5 \mathrm{MPa}, 6.5 \mathrm{MPa}$, and $8 \mathrm{MPa}$ ) in applied at 110 degree Celsius. Bio-boards were successfully produced under the experimental conditions.

\section{MATERIAL AND METHODS}

\subsection{Bioboard Producing Process}

\subsubsection{Raw Material Preparation}

First, the water hyacinth was dried under sunshine for 3 days (8hours a day). Then, materials were cut $(1 \mathrm{~cm} \mathrm{x} 1$ $\mathrm{cm})$ then milled with a Toshiba miller to obtain smaller pieces before it was immersed under water for 168 hours.

\subsubsection{Refining}

After soaking in water for 168 hours, materials became soft due to water absorption into the cells. Materials were refined about 10 minutes with refining machine. The key process in this study was the refining. According to Lumaniaen (2010), refining will give several effects to fibers characteristics such as cutting and shortening of fibers, wall structure, delamination, internal fibrillation/ swelling, curling the fiber or straightening the fiber, and redistribution of hemicelluloses from the interior of the fiber to the exterior.

\subsubsection{Molding Process}

Refined materials were immersed again in water for 7 days to enhance the hydrogen bonding among the cellulose and among the fiber. Furthermore, the materials molded 20 minutes without heat with molding equipment in size $100 \mathrm{~mm} \times 100 \mathrm{~mm}$ then molded 60 minutes at 110-degree Celsius. Producing process was showed in Fig 1.

\subsubsection{Experimental Condition}

In this study water hyacinth was produced with 5 different pressures (2Mpa, 3.5 MPa, 5MPa, 6.5 MPa, and $8 \mathrm{MPa}$ ). The bio-boards were made through 20 minutes without heat molding process, then molded for 60 minutes molding process at $110^{\circ} \mathrm{C}$. In this study the parameters that investigated are bio-board density, bending stress. To determine bio-board's density, first bio-board thickness, dimension and weight was measured. Then, bio-board thickness, dimension, and weight data were calculated into mass $(\mathrm{g})$ and volume $\left(\mathrm{cm}^{3}\right)$ data.

To investigate moisture content, right after test piece was broken by bending test, test piece was inserted into the test container then dried in oven in applied $105^{\circ} \mathrm{c}$ for 24 hours. The test piece was weighed both before and after drying process. Bending test and tensile test were obtained by use of Universal Testing Machine which is connected with sensor and PC to record data automatically during the test. To did bending stress test, 4 specimen tests of each bio-board are prepared at a dimension of specimen test is $50 \mathrm{~mm} \times 20 \mathrm{~mm}$. 3 specimen tests from each bioboard were prepared to conduct tensile test.

\section{RESULT AND DISCUSSION}

Five water hyacinth bio-boards were successfully produced under experimental conditions, shown in Fig.2.

\subsection{Density}

To determine a bio-board's density, first bio-board's thickness, dimension and weight were measured. Then, bio-board thickness, dimension, and weight data were processed into mass $(\mathrm{g})$ and volume $(\mathrm{cm} 3)$ data. Finally, using equation (1) bio-board density data was obtained and process into Figure 2.

$\rho=\frac{m}{v} \quad$ Equation (1)

Where $\rho=$ density $\left(\mathrm{g} / \mathrm{cm}^{3}\right), \mathrm{m}=$ mass $(\mathrm{g}), \mathrm{V}=$ volume $\left(\mathrm{cm}^{3}\right)$ Water hyacinth bio-board densities range $1.057 \mathrm{~g} / \mathrm{cm}^{3}$ $1.279 \mathrm{~g} / \mathrm{cm}^{3}$ which are classified as high-density board based on American National Standard for particle board (1999. It reached highest density at 5MPa pressure while the others achieve the highest density by $8 \mathrm{MPa}$ pressure. Density of $2 \mathrm{MPa}$ and $3.5 \mathrm{MPa}$ bio-board showed not significant difference similar with density of $6.5 \mathrm{MPa}$ and $8 \mathrm{MPa}$ which also not significant difference. Uniformly in fiber size of water hyacinth affect the high density of bioboard. In fact, water hyacinth bio-board were the thinnest board among others, which is explain the tight connection among fibers inside water hyacinth bio-board. Water hyacinth bio-board density shown in Fig.3.

According to American National Standard on Particleboard (1999) High density board define with density above $800 \mathrm{~kg} / \mathrm{m} 3$ (equal with $0.8 \mathrm{~g} / \mathrm{cm}^{3}$ ). Thus, water hyacinth bio-boards was considered as high-density board.

\subsection{Bending stress}

Bending strength testing conduct with Universal Testing Machine, (Shimaizu, Japan) connected with load cell sensor device (Kyowa, Japan) and PC to record data during testing. Measurement method set to bending test, calibration between load cell and PC was checked before conduct the test. Specimen was put on the two parts of UTM device and then force applied from upper side until yield point (over the elastic limit of material).

Bending test data was load $(\mathrm{N})$ and the deflection (mm) that was calculated further with i.e (2). However, from Fig .4 it can be seen that the relation between deflections was proportional with the increase of load starting at 0 until approximately $3 \mathrm{~mm}$ and then gradually decrease after reach peak load. Since Bio-boards are made from biomass the distribution of the cellulose is not uniformly. $\sigma=\frac{3 F L}{2 b h^{2}}$ Equation (2) 
Where $F$ is the load (force) at the fracture point $(\mathrm{N}), L$ is the length of the support span (mm), $b$ is width $(\mathrm{mm}), h$ is thickness (mm).

While the bending test took place, the displacement-load reached its peak at the same time the test piece was broken (permanent damage) and the peak load will represent the maximum load that can be hold by the test piece. Figure below implies at deflection $0 \mathrm{~mm}$ to $7 \mathrm{~mm}$ the stretching bond happened and when the curve gradually decreases it is implies the material unable to stretch anymore.

Water hyacinth bio-board curve (Fig. 5) show wave pattern when bending strength decrease from 51.75 MPa (2MPa bio-board) to 41.56 MPa (3.5 MPa bio-board) and then increase to $48.12 \mathrm{MPa}$ (5MPa bio-board) slightly decrease to $47.64 \mathrm{MPa}$ (6.5 MPa bio-board) and decrease again until $42 \mathrm{MPa}(8 \mathrm{MPa})$. Increasing loading pressure did not have significant effect to bending strength. The best loading pressure to produced high bending strength bio-board with water hyacinth as raw material is $2 \mathrm{MPa}$.

Moisture content analysis for bending and tensile test conducted directly after specimen broken. Water hyacinth bio-board contain of 7 to 9.96 percent moisture content in bending test condition. the moisture content of specimen during the bending test did not give significant impact to the bending strength of material, however the biomass itself that make the different characteristic of material, in this case, bio-board bending strength. This evidence was contrast with Baharoglu et al (2012) research result, that state in some level, increasing moisture content was significantly decreased the mechanical strength properties in particleboard case.

\subsection{Tensile stress}

Tensile strength test was conducted to investigate the maximum force (tensile stress) that bio-board can withstand on before it broke (reach fracture point) and over the elasticity limit..After data recorded data was calculated by follow equation;

$\tau=\frac{F}{A}$

Equation (4)

Where ; $\tau=$ tensile strength $(\mathrm{MPa}), \mathrm{F}=$ force $(\mathrm{N}), \mathrm{A}=$ section area of specimen $\left(\mathrm{mm}^{2}\right)$

Water hyacinth bio-board achieves the highest tensile strength $7.61 \mathrm{MPa}$ by $6.5 \mathrm{MPa}$ bio-board and the lowest tensile strength is $5.73 \mathrm{MPa}$ by $2 \mathrm{MPa}$ bio-board (Fig 6) Water hyacinth tensile strength just obtains $10 \%$ of bending strength as shown in Fig 5. Water hyacinth specimen for tensile strength crack without fibrous edge, Moisture content analyses also conduct right after specimen broke. The aim of moisture content analyses on tensile condition is to observe the current condition when the specimen broken due to the tensile stress. In generally, moisture content on tensile condition is higher than moisture content on bending condition. The range of moisture content on tensile condition is 10.3 percent to 15.5 percent. The result show that tensile strength was lower than bending strength water hyacinth bio-board .

Based on Suboyejo (2004) the resistant of material to deformation strongly depend on the direction of orientation of the load. Since bio-board are made from biomass, which are the cellulose are bounded by hydrogen bound (Van der Wall's force). This is different from metal material that the atoms are bounded by ionic, covalent or metallic bound, which are stronger than hydrogen bounds.

Natural fibers consist of lignin, hemicelluloses, and cellulose. According to Mishra et al. (2004) the elementary unit of cellulose macromolecule is anhydroD-glucose, which contains three alcohol hydroxyls (-OH). These hydroxyls from hydrogen bonds inside the macromolecules itself (intramolecular) and also intermolecular as with hydroxyl groups from the air.

\section{CONCLUSION}

Water hyacinth bio-board densities range $1.057 \mathrm{~g} / \mathrm{cm}^{3}$ $1.279 \mathrm{~g} / \mathrm{cm}^{3}$ which are classified as high-density board based on American National Standard for particle board (1999). water hyacinth bio board average bending rupture stress, tensile strength respectively were 46.21 MPa,. 6.64 MPa. For further research the effect of fiber length and distribution could be observed to obtain more data.

\section{ACKNOWLEDGEMENTS}

The authors are grateful to the research institute and community service UNILA (LPPM UNILA) as research founder through contract number 808 / UN26.21 / PP / 2017 dated July 27, 2017

\section{REFERENCES}

[1] American National Standard. (1999). Particleboard. United State: Composite Panel Associations.

[2] Baharoglu, M., Nemli,G.,Sari,B.,Bardak, S., Ayrilmis,N. (2012). The Influence Of Moisture Content Of Raw Material On The Physical And Mechanical Properties, Surface Roughness, Wettability, And Formalgehyde Emission Of Particleboard Composite. Composite: Part B,43, 2448-2451

[3] FAO. (2009). Industrial Forest Plantation. Center for Forestry Planning working paper No. APFSOSII/WP/2009/13. ROME: FAO.

[4] Gunnarso,C,C. and Petterson,C,M. (2007). Water hyacinth as a resource in agriculture and energy production: A literature review. Waste Management, 27, 117-129. 
[5] Lumiainen J.(2010): Refining of chemical pulp. Papermaking Science and Technology, Book 8, Papermaking Part 1, Stock preparation and wet end pp 87-121. Finland:Fapet Publ

[6] Ministry of Environmental Republic Indonesia. (2012). HutanKayuIndustri [Wood Industry Forest]. (Online)Retrieved ;23 December 2012. From at: http://www.menlh.go.id.

[7] Mishra, S., Monanti,A.K., Drazal,L.T., Misra,M. Hirichsen,G. (2004). A Review On Pineapple Leaf
Fibers, Sisal Fibers And Their Biocomposites. Macromolecul Mater Engineering, 289, 955-974.

[8] Pasaribu and Swahlita (2007).Pengolahan Enceng Gondok Sebagai Bahan Baku Kertas Seni (Processing of Raw Water Hyacinth As Paper Art).Key Papers on Exposure Research Results: Resource Conservation and Rehabilitation Forest. Padang, Indonesia. 20 September 2006.

[9] Suboyejo, M. (2004). Mechanical Properties of Engineered Material. Marcel Dekker. New York

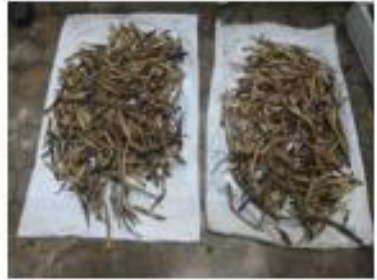

Drying biomass

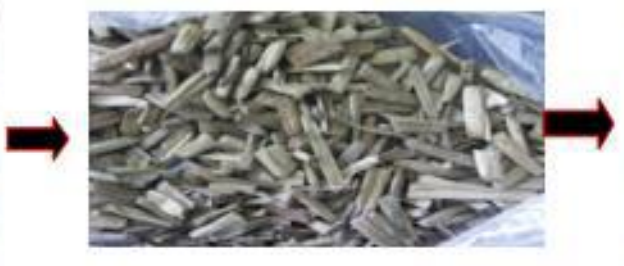

Chopping biomass ( $1 \mathrm{~cm} \mathrm{x}$

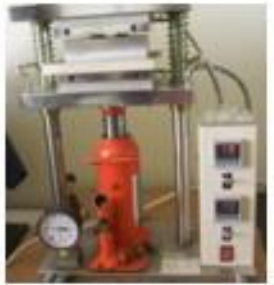

Pressing and molding process

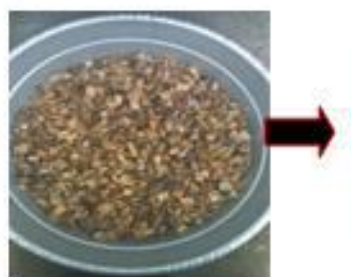

Soaking (168 h)

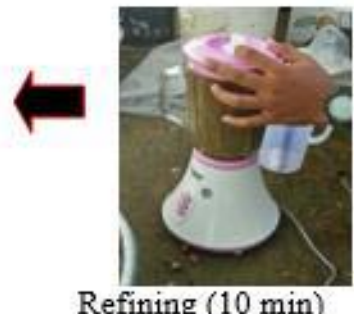

Refining (10 min)

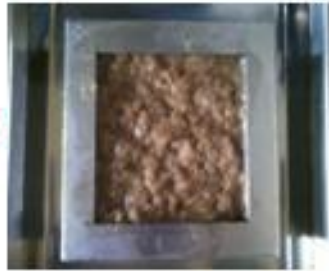

Molding process $(100 \mathrm{~mm} \times 100 \mathrm{~mm})$
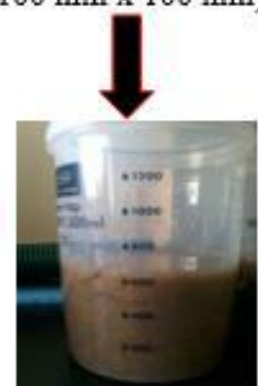

Soaking pulp (168h)

Fig 1: Biodegradabel board producing process

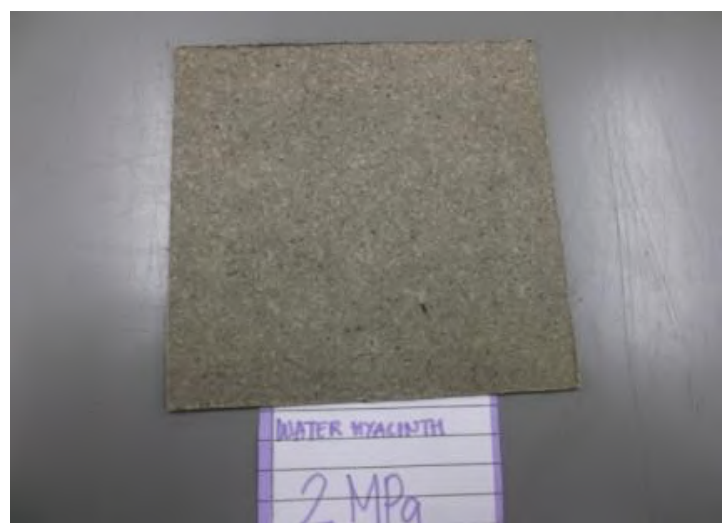

Fig 2. Water hyacinth bio-board successfully produce

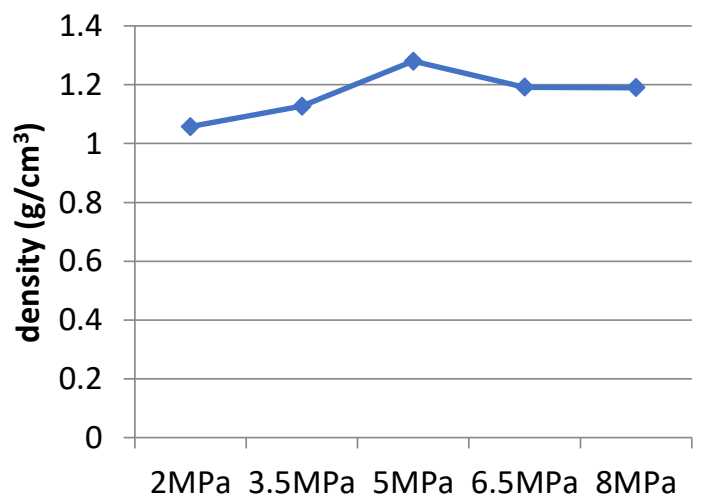

Fig 3. Water hyacinth density 


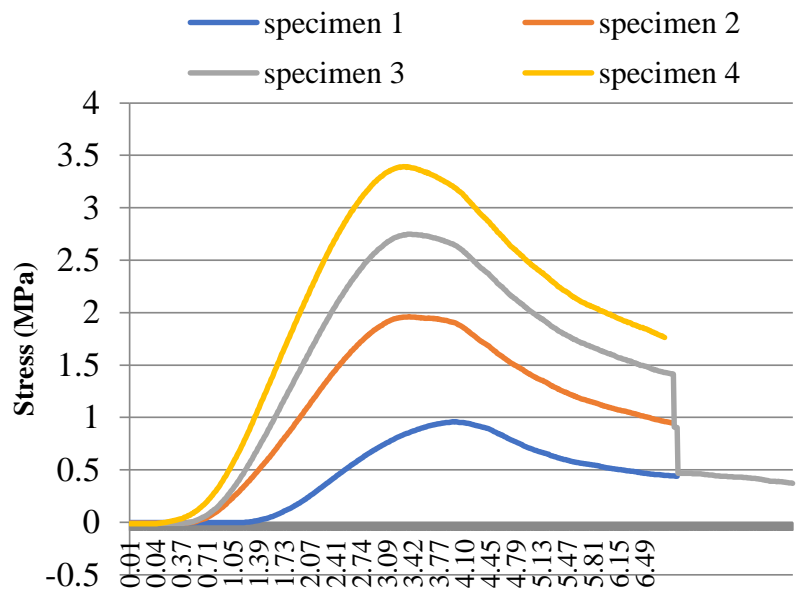

Deflection (mm)

Fig 4. Stress-deflection graph on bending test

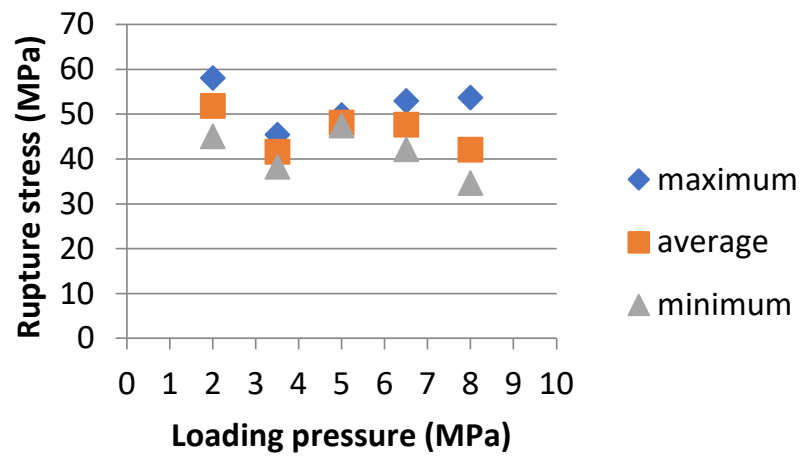

Fig 5. Water hyacinth bio-board rupture bending strength curve

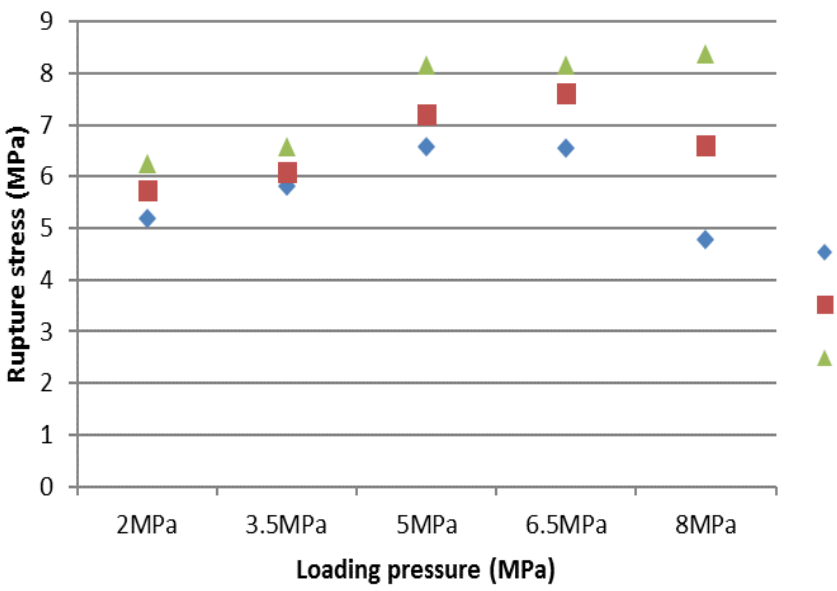

Fig 6. Water hyacinth bio-board tensile strength 